RFP-1416

UC-4 CHEMISTRY

TID-4500 - 54th Ed.

\title{
PREPARATION OF HIGHLY PURE NEPTUNIUM OXIDE
}

\author{
William V. Conner \\ Stephen G. Procter
}

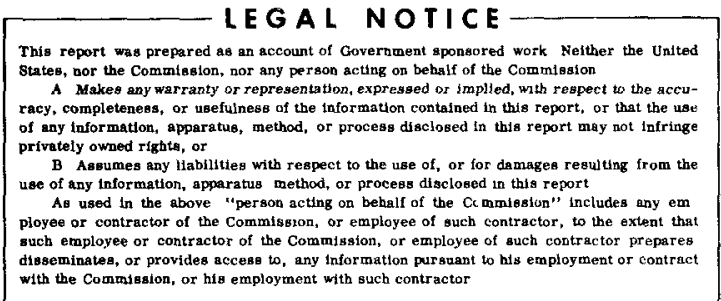

\author{
THE DOW CHEMICAL COMPANY \\ ROCKY FLATS DIVISION \\ P. O. BOX 888 \\ GOLDEN, COLORADO 80401 \\ Prepared under Contract AT(29-1)-1106 \\ for the \\ Albuquerque Operations Office \\ U. S. Atomic Energy Commission
}




\section{DISCLAIMER}

This report was prepared as an account of work sponsored by an agency of the United States Government. Neither the United States Government nor any agency Thereof, nor any of their employees, makes any warranty, express or implied, or assumes any legal liability or responsibility for the accuracy, completeness, or usefulness of any information, apparatus, product, or process disclosed, or represents that its use would not infringe privately owned rights. Reference herein to any specific commercial product, process, or service by trade name, trademark, manufacturer, or otherwise does not necessarily constitute or imply its endorsement, recommendation, or favoring by the United States Government or any agency thereof. The views and opinions of authors expressed herein do not necessarily state or reflect those of the United States Government or any agency thereof. 


\section{DISCLAIMER}

Portions of this document may be illegible in electronic image products. Images are produced from the best available original document. 
CONTENTS

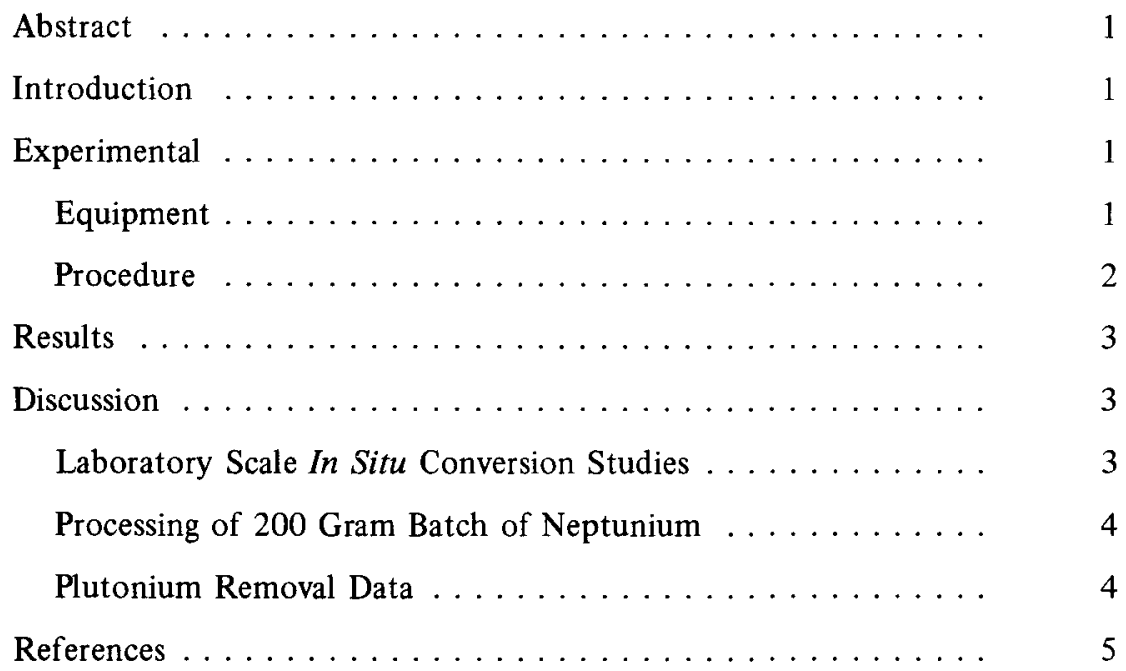




\title{
PREPARATION OF HIGHLY PURE NEPTUNIUM OXIDE
}

\author{
William V. Conner and Stephen G. Procter
}

\begin{abstract}
A 200 gram batch of neptunium was purified using a combined nitrate and chloride anion exchange process. The actinide impurity content of the purified $\mathrm{NpO}_{2}$ product was $<0.1 \mathrm{ppm}$ of plutonium and americium, $<0.2 \mathrm{ppm}$ thorium, and $7 \mathrm{ppm}$ uranium. The total for all impurities was $407 \mathrm{ppm}$.
\end{abstract}

\section{INTRODUCTION}

For several years, the Rocky Flats Plant has been involved in making neptunium metal for other AEC laboratories. ${ }^{1}$ $A$ bomb reduction process has been used to prepare the neptunium metal. An outgrowth of the neptunium metal producing program has been the development of a capability for recovering neptunium from the residues generated by the bomb reduction process. The neptunium program has also expanded into other areas of neptunium purification. Recently, a request was received from Oak Ridge National Laboratory to purify 200 grams of neptunium $\left(\mathrm{NpO}_{2}\right)$ from actinide and common impurities. This report describes the processing used to accomplish the purification.

Previous requests have been received for neptunium metal with a low ${ }^{238} \mathrm{Pu}$ content and for neptunium metal foils. The foils have been used as targets for neutron capture and other radio-chemical experiments. In some cases, the production grade $\mathrm{NpO}_{2}$ received for conversion into metal was contaminated with certain impurities which would have interfered with the anticipated experiments. Consequently, purification of the $\mathrm{NpO}_{2}$ was required before the oxide was converted into metal. ${ }^{2}$

The anion exchange chemistry of neptunium(IV) is analogous to plutonium(IV) and, like plutonium, neptunium can be easily separated from the common metallic impurities using nitrate anion exchange procedures. ${ }^{3}$ Partial separation of neptunium from the actinide elements can be achieved using nitrate form anion exchange resin. Ryan $^{3}$ and Burney ${ }^{4}$ have shown that a separation between neptunium and plutonium can be achieved in a nitrate system if the higher oxidation states of neptunium and plutonium are reduced to $\mathrm{Np}$ (IV) and $\mathrm{Pu}(\mathrm{III})$. The $\mathrm{Np}$ (IV) is adsorbed onto the nitrate form resin while the $\mathrm{Pu}(\mathrm{III})$ remains in the column effluent. However, experience at the Rocky Flats Plant ${ }^{2}$ has shown that the oxidizing nature of nitric acid makes it very difficult to retain all of the plutonium in the $3+$ state. Consequently, some $\mathrm{Pu}(\mathrm{IV})$ is formed and loads onto the nitrate resin.
Uranium(VI) is only weakly adsorbed onto the nitrate resin. But large volumes of wash (20 to 25 column volumes) are required to remove the uranium from the resin bed. Thorium(IV) forms a strong anionic nitrate complex in nitric acid and will load along with the neptunium onto nitrate form resin.

Several analytical schemes have been investigated for the separation of neptunium from the other actinides using chloride form anion exchange resin. ${ }^{5,6,7}$ The procedure for separating plutonium from neptunium in the chloride system is similar to the procedure for the nitrate system. The Np(IV) is adsorbed onto the chloride form resin and the $\mathrm{Pu}(\mathrm{III})$ is not. However, the gradual oxidation of Pu(III) to Pu(IV) which occurs in the nitrate system is not encountered in the chloride system. Uranium(VI) is adsorbed along with neptunium onto chloride form resin, but the neptunium can be selectively eluted by controlling the acidity of the eluate.

Thorium(IV) does not form adsorbable anionic chloride complexes in strong hydrochloric acid, and therefore will not load onto chloride form resin.

Neptunium anion exchange processing at Rocky Flats has been performed using both the nitrate and the chloride systems. The nitrate system is very effective for separating neptunium from the common metallic impurities, whereas the chloride system has been found to be superior to the nitrate system for separating neptunium from the actinide elements. Therefore, to purify the 200 gram batch of neptunium from the actinide and common impurities, a combined nitrate and chloride anion exchange process was utilized. The neptunium was received as $\mathrm{NpO}_{2}$. The concentration of the actinide elements in the purified $\mathrm{NpO}_{2}$ was to be as low as possible. A reduction in the overall level of the common metallic impurities was also required. The concentrations of the common metallic impurities were reduced using nitrate anion exchange techniques. The actinide impurities were removed using chloride anion exchange techniques.

\section{EXPERIMENTAL}

Equipment: The glovebox used for this project was a 12 -foot-long alpha containment glovebox. Since the glovebox had previously been used for processing plutonium and americium, it was thoroughly cleaned before this project was started. The cleaning was accomplished by first washing the entire inside surface with water. The 
inside of the box was then coated with a layer of latex rubber. After drying, the rubber coating was stripped off along with the adhering dirt and any actinide contamination. This procedure was repeated and the inside of the glovebox was painted with an acid resistant paint to provide a clean working surface.

The ion column used for this project was a 6 inch diameter by 2 -foot-long glass column with polyvinyl chloride (PVC) end plates. The column had a capacity of 10 liters of resin, and a cross sectional area of $180 \mathrm{~cm}^{2}$. The column was loaded with Dowex® 1-X4, 50-100 mesh nitrate form anion exchange resin. The resin was conditioned with 2 column volumes of $6.5 \mathrm{MHNO}_{3}-0.1 \mathrm{M}$ ferrous sulfate $\left(\mathrm{FeSO}_{4}\right)-0.1 \mathrm{M}$ hydrazine $\left(\mathrm{N}_{2} \mathrm{H}_{4}\right)$ before being used. As used in this report, a column volume refers to the volume of the column before the resin was added.

A schematic diagram of the ion column system is shown in Figure 1. The adjusted feed solutions were placed in a 4 liter beaker and pumped from the beaker through the column using a Master-Flex ${ }^{\circledR}$ tubing pump. A recycle loop was used in the system to aid in controlling the feed rate to the column. The feed and wash solutions were fed to the bottom of the column. The direction of flow was reversed for the elution step with the column being eluted from top to bottom.

Procedure: The $\mathrm{NpO}_{2}$ feed was contacted with 2 liters of concentrated $\mathrm{HNO}_{3}-0.1 \mathrm{MHF}$ at $100^{\circ} \mathrm{C}$ for two hours. Three contacts with fresh acid were required for complete dissolution of the $\mathrm{NpO}_{2}$. The acidity of the solution was adjusted to $6.5 \mathrm{M} \mathrm{H}^{+}$with distilled water. The solution was made $0.1 M$ in $\mathrm{N}_{2} \mathrm{H}_{4}$ and $0.1 M$ in $\mathrm{FeSO}_{4}$ to adjust the oxidation states of neptunium and plutonium to $\mathrm{Np}$ (IV) and $\mathrm{Pu}(\mathrm{III})$. The $\mathrm{N}_{2} \mathrm{H}_{4}$ was added ahead of the $\mathrm{FeSO}_{4}$ reductant to destroy any nitrous acid present. The $\mathrm{N}_{2} \mathrm{H}_{4}$ must be added first or the nitrous acid will destroy the reducing value of the $\mathrm{FeSO}_{4}$.

The adjusted feed solution was pumped through the column at a rate of $10 \mathrm{mg} \mathrm{Np} / \mathrm{min} / \mathrm{cm}^{2}$ of column area. The column was washed with 5 column volumes of $6.5 \mathrm{M}$ $\mathrm{HNO}_{3}-0.1 M \mathrm{FeSO}_{4}-0.1 M \mathrm{~N}_{2} \mathrm{H}_{4}$, followed by 5 column volumes of $6.5 \mathrm{MHNO}_{3}-0.1 \mathrm{MN}_{2} \mathrm{H}_{4}$. The column was then washed with 4 column volumes of concentrated $\mathrm{HCl}-0.1 M$ hydroxylamine hydorchloride $\left(\mathrm{NH}_{2} \mathrm{OH} \cdot \mathrm{HCl}\right)$ to convert the resin from the nitrate to the chloride form. This was followed by 2 column volumes of concentrated $\mathrm{HCl}-0.1 M \mathrm{HI}$ to reduce any $\mathrm{Pu}(\mathrm{IV})$ which may have

Figure 1. Schematic diagram of ion column system.

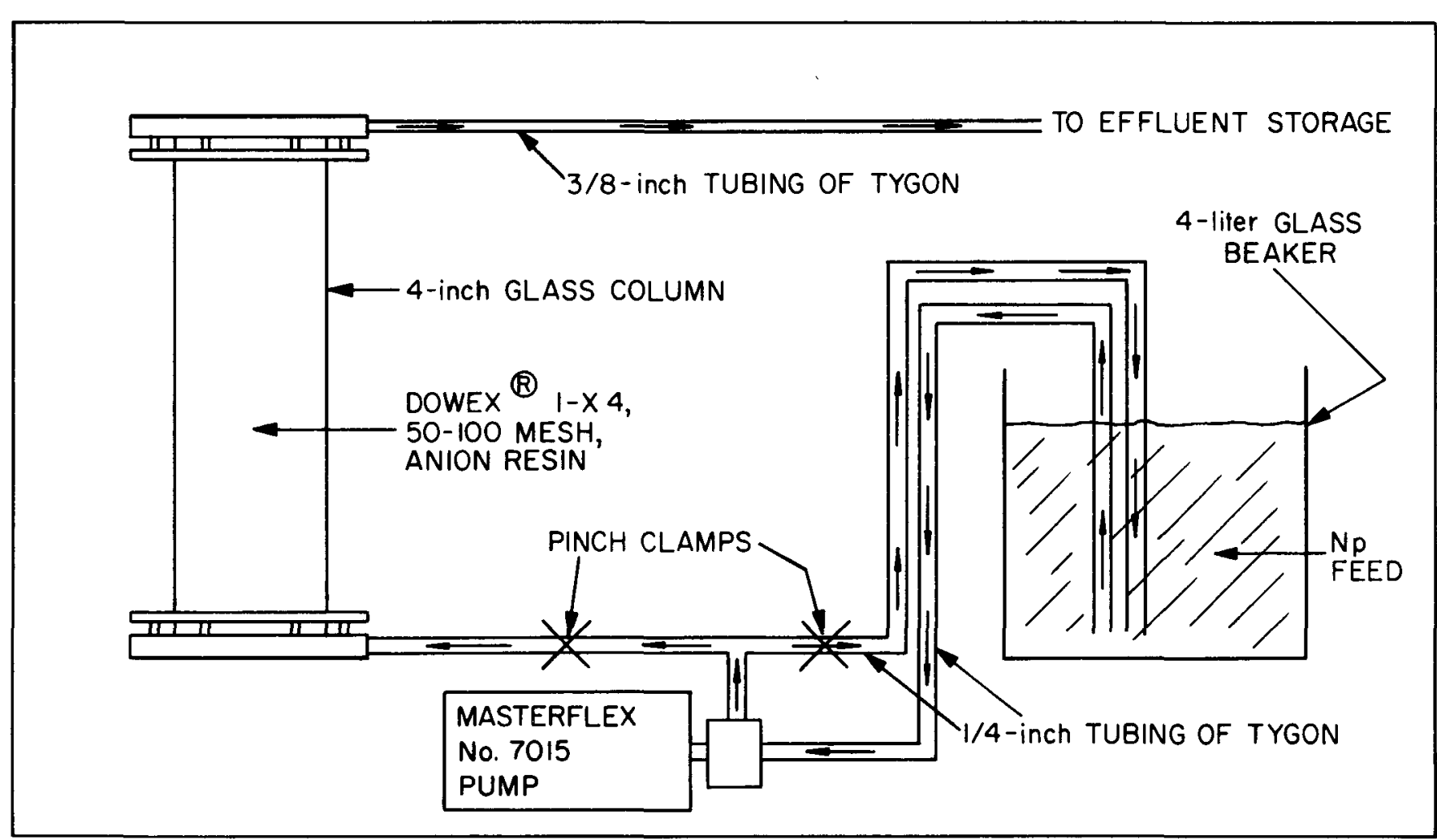


loaded onto the resin to $\mathrm{Pu}(\mathrm{III})$. The column was then washed with an additional 6 column volumes of concentrated $\mathrm{HCl}-0.1 \mathrm{MNH}_{2} \mathrm{OH} \cdot \mathrm{HCl}$ to remove any residual $\mathrm{Pu}(\mathrm{III})$. The neptunium was eluted with 3 column volumes of $5 \mathrm{M} \mathrm{HCl}$.

The ion column was prepared for a second chloride pass by first washing the resin with 1 column volume of water to remove any residual uranium. The resin was then reconditioned with 2 column volumes of concentrated $\mathrm{HCl}-0.1 M \mathrm{HI}$. The chloride concentration of the eluate from the first pass was increased to $10.5 \mathrm{M}$ by the addition of $\mathrm{LiCl}$ and the solutions were made $0.1 \mathrm{M}$ in $\mathrm{HI}$. The feed solutions were pumped through the column at $10 \mathrm{mg} \mathrm{Np} / \mathrm{min} / \mathrm{cm}^{2}$ and the column was washed with 10 column volumes of concentrated $\mathrm{HCl} \cdot 0.1 \mathrm{M}$ $\mathrm{NH}_{2} \mathrm{OH} \cdot \mathrm{HCl}$. The neptunium was again eluted with $5 \mathrm{M} \mathrm{HCl}$.

The purified neptunium was removed from the chloride eluate as an oxalate by precipitating with oxalic acid. The acidity of the eluate solution was adjusted to $2.5 \mathrm{M}$ with distilled water and ascorbic acid (1 gram ascorbic acid/ gram neptunium) was added to reduce the higher oxidation states of neptunium to $\mathrm{Np}(\mathrm{IV})$. The solutions were heated to $60^{\circ} \mathrm{C}$ and solid oxalic acid was added in sufficient quantities to precipitate the neptunium and leave the solution $0.1 M$ in oxalic acid. The neptunium oxalate was calcined at $600^{\circ} \mathrm{C}$ for 6 hours. After cooling, the material was recalcined at $700^{\circ} \mathrm{C}$ for 6 hours to ensure complete conversion to $\mathrm{NpO}_{2}$. The calcined $\mathrm{NpO}_{2}$ was sampled for radiometric and spark source mass spectroscopic analysis.

\section{RESULTS}

A comparison of actinide impurities in the $\mathrm{NpO}_{2}$ received from ORNL and the purified product is given in Table $\mathrm{I}$. The starting $\mathrm{NpO}_{2}$ contained 1838 ppm of actinide impurities. The only detectable actinide impurity in the purified product was uranium at a concentration of $7 \mathrm{ppm}$.

Table I. Comparison of actinide impurities in starting and purified $\mathrm{NpO}_{2}$.

\begin{tabular}{|c|c|c|c|c|c|}
\hline & \multicolumn{5}{|c|}{ Concentrations (ppm)* } \\
\hline & ${ }^{238} \mathrm{Pu}^{* *}$ & $239-2400 \mathrm{Pu}^{* *}$ & ${ }^{241} \mathrm{Am}^{* *}$ & $\mathrm{U}^{* * *}$ & $\mathbf{T h} * * *$ \\
\hline Starting $\mathrm{NpO}_{2}$ & 750 & 150 & 0.64 & 700 & 238 \\
\hline Purified $\mathrm{NpO}_{2}$ & $<0.1$ & $<0.1$ & $<0.1$ & 7 & $<0.2$ \\
\hline
\end{tabular}

\footnotetext{
*Impurities are given as $\mu \mathrm{g}$ impurity per gram neptunium.

** Results obtained by radiometric procedures.

*** Results obtained by spark source mass spectroscopic analysis.
}

The ${ }^{238} \mathrm{Pu},{ }^{239-240} \mathrm{Pu}$, and ${ }^{241} \mathrm{Am}$ concentrations were all $<0.1 \mathrm{ppm}$. The thorium content was $<0.2 \mathrm{ppm}$.

A complete analysis of the high purity $\mathrm{NpO}_{2}$ is given in Table II. The purified $\mathrm{NpO}_{2}$ contained $400 \mathrm{ppm}$ of nonactinide impurities. The major impurities were carbon (150 ppm), calcium (48 ppm) and chlorine (100 ppm). Excluding these three elements, the concentrations of the other impurities were all $<20 \mathrm{ppm}$ and the final impurity total for the other 25 detectable impurities was $109 \mathrm{ppm}$.

\section{DISCUSSION}

Laboratory Scale In Situ Conversion Studies: The in situ conversion of nitrate form resin to chloride form had been tested at Rocky Flats ${ }^{8}$ before this purification project was started. The in situ conversion was tested initially on a small, 50-milliliter column to determine if any unforeseen problems existed. The results of this test were encouraging enough to proceed with the conversion on a large scale. The conversion was tested next on a 66 gram batch of neptunium using a 2 liter column. This test was conducted by loading from $6.5 \mathrm{MHNO}_{3}-0.1 \mathrm{M}$ $\mathrm{FeSO}_{4}-0.1 M \mathrm{~N}_{2} \mathrm{H}_{4}$. The column was then washed with 10 column volumes of $6.5 \mathrm{MHNO}_{3}$ followed by 10 column volumes of concentrated $\mathrm{HCl}-0.1 \mathrm{M} \mathrm{NH} \mathrm{NH}_{2} \mathrm{OH} \cdot \mathrm{HCl}$. There were no problems associated with the conversion except for some gas evolution while the column was exposed to both $\mathrm{HNO}_{3}$ and $\mathrm{HCl}$.

Table II. Spark source mass spectroscopic analysis of high purity neptunium oxide.

\begin{tabular}{|c|c|c|c|}
\hline Element & $\begin{array}{c}\text { Concentration } \\
\text { ppm }^{*}\end{array}$ & Element & $\begin{array}{c}\text { Concentration } \\
\text { ppm* }\end{array}$ \\
\hline${ }^{241} \mathrm{Am}^{* *}$ & $<0.1$ & $\mathbf{K}$ & 7 \\
\hline${ }^{238} \mathrm{Pu}^{* *}$ & $<0.1$ & $\mathbf{M g}_{\mathbf{g}}$ & 2 \\
\hline${ }^{239-240} \mathrm{Pu}^{* *}$ & $<0.1$ & $\mathbf{M n}$ & 0.3 \\
\hline Th & $<0.2$ & $\mathbf{N}$ & 2 \\
\hline $\mathrm{U}$ & 7 & $\mathrm{Na}$ & 8 \\
\hline $\mathbf{A l}$ & 16 & $\mathbf{N i}$ & 0.9 \\
\hline As & 0.2 & $\mathbf{P}$ & 1 \\
\hline $\mathbf{B}$ & 2 & $\mathbf{P b}$ & 0.4 \\
\hline C & 150 & $\mathbf{S}$ & 7 \\
\hline $\mathbf{C a}$ & 48 & $\mathrm{Se}$ & 7 \\
\hline Cl & 100 & $\mathbf{S i}$ & 17 \\
\hline Cr & 3 & $\mathrm{Sr}$ & 0.6 \\
\hline $\mathrm{Cu}$ & 2 & $\mathbf{T a}$ & 8 \\
\hline $\mathbf{F}$ & 1 & $\mathbf{T i}$ & 2 \\
\hline $\mathbf{F e}$ & 10 & $\mathbf{V}$ & 0.2 \\
\hline $\mathrm{Ga}$ & 0.1 & $\mathbf{Z n}$ & 2 \\
\hline In & 2 & & \\
\hline
\end{tabular}

\footnotetext{
*Impurities are given as $\mu \mathrm{g}$ impurity per gram neptunium. Only detectable impurities are listed.

** These results obtained by radiometric procedures.
} 
The plutonium decontamination was much poorer than expected. The feed contained $1303 \mu \mathrm{g}{ }^{238} \mathrm{Pu}$ per gram $\mathrm{Np}$ and the eluate contained $78 \mu \mathrm{g}^{238} \mathrm{Pu}$ per gram of $\mathrm{Np}$. This gave a plutonium decontamination factor of only 16 . The probable cause of the poor decontamination was attributed to the partial oxidation of $\mathrm{Pu}$ (III) to $\mathrm{Pu}$ (IV) by the nitric acid. The Pu(IV) would have loaded onto the resin. The $\mathrm{NH}_{2} \mathrm{OH} \cdot \mathrm{HCl}$ reductant used for the $\mathrm{HCl}$ wash apparently was not strong enough to reduce the loaded $\mathrm{Pu}(\mathrm{IV})$ to $\mathrm{Pu}$ (III). Based on these data, a reducing step using HI as the reductant was included in the first column pass for this project.

Processing of 200 Gram Batch of Neptunium: The $\mathrm{N}_{2} \mathrm{H}_{4}$ and $\mathrm{FeSO}_{4}$ were added to the nitrate ion column feed to reduce the higher oxidation states of neptunium and plutonium to $\mathrm{Np}$ (IV) and $\mathrm{Pu}$ (III), respectively. The acidity of the solution from the dissolution step was adjusted to $6.5 \mathrm{M} \mathrm{H}^{+}$by the addition of distilled water. The solution was allowed to cool following the dilution before the hydrazine was added. The stability of hydrazine in nitric acid decreases markedly with increased temperature. The hydrazine was added first to destroy any nitrous acid present. Nitrous acid rapidly oxidizes Fe(II) and $\mathrm{Fe}$ (III) and destroys its value as a reducing agent.

The first pass over the ion column was started in the nitrate system and completed in the chloride system. The neptunium was loaded from the nitric acid solution. The loaded column was washed first with nitric acid and then with concentrated hydrochloric acid. The $\mathrm{HCl}$ wash converted both the resin and the loaded complexes from the nitrate to chloride form. This in situ conversion reduced the time, the effort, and the neptunium losses which would have been incurred had a separate chloride pass been used. The in situ conversion eliminated the elution of the neptunium from the nitrate column, and the subsequent precipitation and redissolution of the neptunium in concentrated $\mathrm{HCl}$ which would have been required for a separate chloride pass.

After conversion of the resin to the chloride form was completed, the column was washed with concentrated $\mathrm{HCl}-0.1 \mathrm{M} \mathrm{HI}$. The HI served as a reductant. The $\mathrm{HI}$ wash was carried out to ensure that all the plutonium remaining on the resin was reduced to the $3+$ state. The column was then washed with additional concentrated $\mathrm{HCl} \cdot 0.1 M \mathrm{NH}_{2} \mathrm{OH} \cdot \mathrm{HCl}$ to remove the remaining plutonium and thorium. The $\mathrm{NH}_{2} \mathrm{OH} \cdot \mathrm{HCl}$ was included in the acid wash as a holding reductant to minimize the loss of neptunium.

The eluate from the first column pass was sampled for ${ }^{238} \mathrm{Pu}$ to determine if an additional pass would be required. The analysis showed that the ${ }^{238} \mathrm{Pu}$ concentration had been reduced from $750 \mu \mathrm{g} / \mathrm{g} \mathrm{Np}$ to $6.5 \mu \mathrm{g} / \mathrm{g} \mathrm{Np}$. Since the ${ }^{238} \mathrm{Pu}$ concentration was still above the specification level, the eluate was prepared for a second pass over the column.

The resin was first washed with $\mathrm{H}_{2} \mathrm{O}$ to remove the uranium and then reconditioned with concentrated $\mathrm{HCl}$ $0.1 M \mathrm{HI}$. The chloride ion concentration in the eluate from the first pass was increased to $10.5 \mathrm{M}$ with $\mathrm{LiCl}$. Following the second pass over the chloride column, the ${ }^{238} \mathrm{Pu}$ concentration in the eluate was less than the detectable limit of $0.1 \mu \mathrm{g}{ }^{238} \mathrm{Pu} / \mathrm{g} \mathrm{Np}$. The uranium and thorium concentrations were also less than the detectable limit, but the lower limit of the X-ray fluorescence analytical method used for process control analysis of the eluate was $10 \mu \mathrm{g} \mathrm{Th} / \mathrm{g} \mathrm{Np}$ and $10 \mu \mathrm{g} \mathrm{U} / \mathrm{g} \mathrm{Np}$. The neptunium was precipitated with oxalic acid and calcined to $\mathrm{NpO}_{2}$. The purified $\mathrm{NpO}_{2}$ was sampled for final impurity analysis.

Plutonium Removal Data: Both the nitrate and chloride effluent and wash from the first column pass were sampled to determine which step gave the most efficient plutonium removal. The nitrate effluent and wash solutions were collected in one large storage tank, and only one sample

Table III. Removal of plutonium-238 from first column pass.

\begin{tabular}{|c|c|c|c|}
\hline Type of Solution & $\begin{array}{l}\text { Total } \\
\text { Volume } \\
\text { (liters) }\end{array}$ & $\begin{array}{l}{ }^{238} \mathrm{Pu} \\
\text { Concentration } \\
\text { (grams/liter) }\end{array}$ & $\begin{array}{c}\text { Total } \\
\text { Grams of } \\
{ }^{238} \mathrm{Pu} \text { in } \\
\text { Solution }\end{array}$ \\
\hline $\begin{array}{l}\text { Nitrate Effluent } \\
\text { and Wash }\end{array}$ & 108 & $7.1 \times 10^{-5}$ & 0.00767 \\
\hline \multicolumn{4}{|l|}{$\begin{array}{l}\text { First Half of } \\
\text { Chloride Wash, } \\
\text { Bottle No. }\end{array}$} \\
\hline 1 & 8 & $5.8 \times 10^{-5}$ & 0.000464 \\
\hline 2 & 8 & $2.1 \times 10^{-5}$ & 0.000168 \\
\hline $\mathbf{3}$ & 8 & $7.5 \times 10^{-7}$ & 0.000006 \\
\hline 4 & 8 & $2.2 \times 10^{-6}$ & 0.000018 \\
\hline 5 & 8 & $1.4 \times 10^{-6}$ & 0.000011 \\
\hline 6 & 8 & $8.2 \times 10^{-6}$ & 0.000066 \\
\hline 7 & 8 & $1.6 \times 10^{-6}$ & 0.000013 \\
\hline 8 & 8 & $9.4 \times 10^{-6}$ & 0.000075 \\
\hline First Half Totals & 64 & $\overline{1.28 \times 10^{-5}}$ & 0.000820 \\
\hline \multicolumn{4}{|l|}{$\begin{array}{l}\text { Second Half of } \\
\text { Chloride Wash, } \\
\text { Bottle No. }\end{array}$} \\
\hline 9 & 8 & $1.6 \times 10^{-3}$ & 0.0128 \\
\hline 10 & 8 & $7.7 \times 10^{-3}$ & 0.0616 \\
\hline 11 & 8 & $1.5 \times 10^{-3}$ & 0.0120 \\
\hline 12 & 8 & $8.6 \times 10^{-5}$ & 0.000690 \\
\hline 13 & 8 & $4.3 \times 10^{-5}$ & 0.000344 \\
\hline 14 & 8 & $1.8 \times 10^{-4}$ & 0.00144 \\
\hline 15 & 8 & $3.2 \times 10^{-5}$ & 0.000256 \\
\hline 16 & 8 & $2.6 \times 10^{-3}$ & 0.000208 \\
\hline Second Half Totals & 64 & $1.39 \times 10^{-3}$ & 0.089336 \\
\hline
\end{tabular}


could be taken of the combined solutions. The chloride wash solutions were collected in 8-liter bottles and a sample was taken from each bottle. The samples were analyzed for ${ }^{238} \mathrm{Pu}$ and the results of these analyses are shown in Table III.

The data in Table III show that $7.74 \%$ of the ${ }^{238} \mathrm{Pu}$ in the starting $\mathrm{NpO}_{2}$ was removed with the nitrate effluent and wash. An additional $0.83 \%$ of the ${ }^{238} \mathrm{Pu}$ was removed with the first half of the chloride wash, and $90.19 \%$ of the ${ }^{238} \mathrm{Pu}$ was removed with the second half of the chloride wash. The first half of the chloride wash was required to remove all the $\mathrm{HNO}_{3}$ from the column and fill the column with concentrated $\mathrm{HCl} \cdot 0.1 \mathrm{MHI}$. The column was allowed to stand overnight after the first half of the chloride wash. This allowed sufficient time for the reduction of any residual $\mathrm{Pu}$ (IV) to $\mathrm{Pu}$ (III). These data readily demonstrate that the majority of the ${ }^{238} \mathrm{Pu}$ was not removed until the $\mathrm{NHO}_{3}$ had been replaced with concentrated $\mathrm{HCl}-0.1 \mathrm{MHI}$.

\section{REFERENCES}

1. D. L. Baaso, W. V. Conner, and D. A. Burton, "Production of Neptunium Metal on a 100-400 Gram Scale," RFP-1032, Rocky Flats Division, The Dow Chemical Company, December 5, 1967.
2. W. V. Conner and D. L. Baaso, "Preparation of Radiochemically Pure Neptunium Metal Foils," RFP-1415, Rocky Flats Division, The Dow Chemical Company, December 30, 1969

3. J. L. Ryan, "Concentration and Final Purification of Neptunium by Anion Exchange," HW-59193, Rev. September 3, 1959.

4. G. A. Burney, "Separation of Neptunium and Plutonium by Anion Exchange," DP-689, April 1962.

5. F. Nelson, D. C. Michelson, and J. H. Holloway, "Ion Exchange Procedures III, Separation of Uranium, Neptunium and Plutonium," J. Chromatog., 14, (1964), pp. 258-260.

6. N. Jackson and J. R. Short, "The Separation of Neptunium and Plutonium by Ion Exchange," AERE-M444, July 1959.

7. F. P. Roberts and F. P. Bauer, "Sequential Separation of Some Actinide Elements by Anion Exchange," HW-60552, June 1, 1959.

8. D. L. Baaso and W. V. Conner, unpublished data, Rocky Flats Division, The Dow Chemical Company. 